\title{
Molecular Investigation of Tick-Borne Pathogens in Ticks removed from Tick- Bitten Humans in the Republic of Korea
}

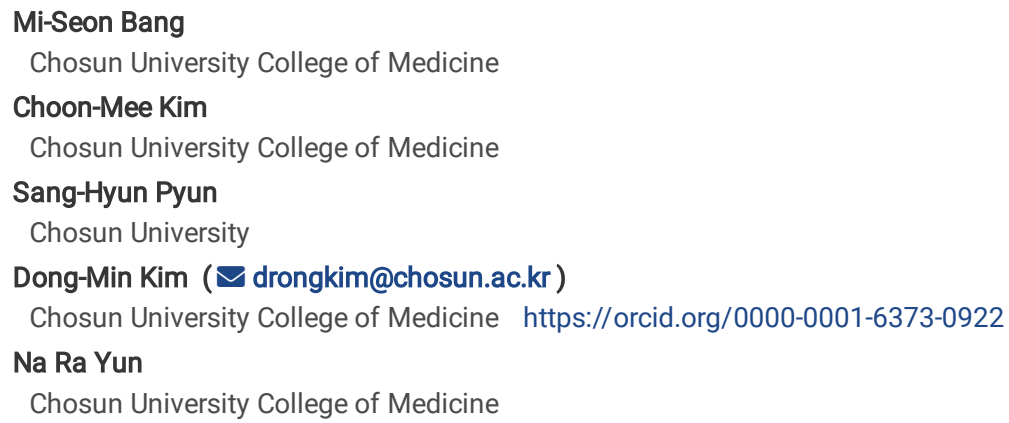

Research

Keywords: Ticks, Tick bites, Tick-borne infections, Tick-borne diseases

Posted Date: December 20th, 2019

DOI: https://doi.org/10.21203/rs.2.19431/v1

License: (c) (1) This work is licensed under a Creative Commons Attribution 4.0 International License. Read Full License 


\begin{abstract}
Background Tick-borne infections are continuously increasing due to climate change, increased outdoor activities and increased travel between countries. This study was to investigate the presence of tick-borne pathogens in ticks removed from tick-bitten humans in southwest provinces of Republic of Korea (ROK).
\end{abstract}

Methods Ticks were obtained from those tick-bitten humans between May 2014 and September 2017 in Jeollanam provinces and Gwangju metropolitan city in ROK. The presence of the tick-borne pathogens in ticks removed from tick-bitten humans was analyzed using pathogen-specific polymerase chain reaction (PCR).

Results We identified 33 ticks from three tick species, namely Amblyomma testudinarium (60.6\%), Haemaphysalis longicornis (27.3\%), and Ixodes nipponensis (12.1\%) in order of occurrence by morphology and 16S rDNA-targeting PCR. Tick-borne pathogens were found in 16 ticks using pathogen-specific PCR. From the results, 12 ticks (36.4\%) tested positive for spotted fever group (SFG) Rickettsia: Rickettsia monacensis (1/12), R. tamurae (8/12), and Candidatus Rickettsia jingxinensis (3/12). Three ticks (9.1\%) were positive for Anaplasma phagocytophilum . In addition, three ticks (9.1\%) tested positive for Babesia gibsoni (1/3) and B. microti (2/3).

Conclusions In conclusion, we identified three tick species; the most common species was A. testudinarium followed by $\mathrm{H}$. longicornis and I. nipponensis . SFG Rickettsia , A. phagocytophilum , and Babesia spp. were the most frequently detected pathogens in ticks removed from tick-bitten humans. R. tamurae and Ca. R. jingxinensis were firstly detected in Korea. The present results will contribute to the understanding of tick-borne infections in animals and humans in the ROK.

\title{
Background
}

Ticks are major vectors of pathogens such as bacteria, viruses, and protozoans. These arthropods can transmit a variety of diseases to humans and animals (1). Tick-borne diseases are caused by viral or bacterial pathogens transmitted through tick bites. Several tick-borne diseases such as Lyme disease (caused by Borrelia species), spotted fever group rickettsioses (caused by Rickettsia spp.), anaplasmosis (caused by Anaplasma phagocytophilum), bartonellosis (caused by Bartonella spp.), Q fever (caused by Coxiella burnetii), and babesiosis (caused by Babesia spp.) have been reported in the Republic of Korea (ROK) (2).

The incidence of tick-borne diseases in the ROK is increasing due to global warming, increased outdoor activities, and increased international travel. The growing number of tick bites each year poses an escalating risk of tick-borne diseases (2). Few studies have investigated the prevalence of tick-borne pathogens in ticks removed from tick-bitten humans in the ROK. However, it is necessary to determine the extent of tick-borne pathogens in the ROK, and to characterize them.

The present study aimed to investigate the presence of tick-borne pathogens in ticks removed from humans in the southwest provinces of the ROK. Our study detected the DNA of tick-borne pathogens from ticks using pathogen-specific nested PCR. The results of this study will contribute to the understanding of the interaction between ticks and pathogens that cause diseases in humans.

\section{Methods}

\section{Tick samples}

Ticks were removed from humans between May 2014 and September 2017 in the Jeollanam Provinces and Gwangju Metropolitan City in the ROK. All ticks were morphologically identified according to species and life stage using a microscope and standard taxonomic keys. Ticks were washed in $70 \%$ ethanol, rinsed twice with sterile phosphate-buffered saline (PBS), added to a hard tissue grinding MK28 tube (Bertin Technology, Rockville, MD, USA) containing 800 $\mu \mathrm{L}$ of PBS with $1 \times \mathrm{PC} / \mathrm{SM}$ (penicillin and streptomycin), ground using a FastPrep ${ }^{\circledR}-24$ Classic instrument (MP Biomedicals, Solon, OH, USA), and stored at $-80^{\circ} \mathrm{C}$ until used for DNA extraction.

\section{DNA extraction}

We mixed $150 \mu \mathrm{L}$ of the ground tick with $150 \mu \mathrm{L}$ buffer ATL and $20 \mu \mathrm{L}$ proteinase $\mathrm{K}$, and incubated at $56^{\circ} \mathrm{C}$ overnight for lysis; the genomic DNA was extracted using a QIAamp Tissue \& Blood Mini Kit (Qiagen, Hilden, Germany) according to the manufacturer's instructions. DNA was eluted into $50 \mu \mathrm{L}$ TE buffer and stored at $-20^{\circ} \mathrm{C}$ until PCR amplification.

\section{Polymerase Chain Reaction (PCR)}

To detect the presence of Rickettsia DNA, the outer membrane protein A gene (ompA), citrate synthase gene (gltA), and a $17 \mathrm{kDa}$ protein gene (17 kDa) of the spotted fever group Rickettsia species were targeted. The heat shock protein gene (groEL) and the ankyrin-related protein gene (ankA) were targeted to detect A. phagocytophilum. To detect the presence of Borrelia DNA, the CTP synthase gene (pyrG) was targeted. The 16S-23S internal transcribed spacer region (ITS) was targeted to detect Bartonella species. The htpAB-associated repetitive element (IS1111) was targeted to detect Coxiella species. To detect the presence of Babesia species, 18S rDNA was targeted. To identify tick species, conventional PCR targeting the mitochondrial 16S rRNA gene (16S rDNA) was performed. All PCR primers used for detecting tick-borne pathogens, PCR conditions, and product sizes are given in Table 1. Conventional PCR (C-PCR) was performed in 20 $\mu \mathrm{L}$ reaction volumes using the AccuPowerR PCR PreMix (Bioneer Corp., Korea). Each PCR mixture consisted of $16 \mu \mathrm{L}$ of distilled water, $1 \mu \mathrm{L}$ of each primer (10 pmol $/ \mu \mathrm{L}$ ), and $2 \mu \mathrm{L}$ of genomic DNA as template DNA. For 16S rDNA C-PCR and 18S rDNA nested PCR (N-PCR), we performed PCR using AmpliTaq Gold 360 Master Mix (Applied Biosystems, CA, USA) instead of AccuPowerR PCR PreMix. 
Table 1

Oligonucleotide primers and PCR conditions used for the detection of tick-borne pathogens in ticks removed from tick-bitten humans.

\begin{tabular}{|c|c|c|c|c|c|c|c|c|c|}
\hline \multirow[t]{2}{*}{ Identification } & \multirow{2}{*}{$\begin{array}{l}\text { Target } \\
\text { gene }^{a}\end{array}$} & \multirow{2}{*}{$\begin{array}{l}\text { Primer } \\
\text { name }\end{array}$} & \multirow[t]{2}{*}{ Nucleotide sequence $\left(5^{\prime}-3^{\prime}\right)$} & \multirow{2}{*}{$\begin{array}{l}\text { Product } \\
\text { size } \\
\text { (bp) }\end{array}$} & \multicolumn{4}{|c|}{ PCR conditions $\left({ }^{\circ} \mathrm{C} / \mathrm{sec}\right)$} & \multirow[t]{2}{*}{ Refer } \\
\hline & & & & & Denaturation & Annealing & Extension & Cycles & \\
\hline \multirow{12}{*}{$\begin{array}{l}\text { Rickettsia } \\
\text { species }\end{array}$} & \multirow[t]{4}{*}{ ompA } & RR190.70F & ATGGCGAATATTTCTCCAAAAA & \multirow[t]{2}{*}{634} & \multirow[t]{2}{*}{$94 / 30$} & \multirow[t]{2}{*}{$50 / 30$} & \multirow[t]{2}{*}{$72 / 60$} & \multirow[t]{2}{*}{40} & \multirow[t]{2}{*}{$(3,4)$} \\
\hline & & RR190.701R & GTTCCGTTAATGGCAGCATCT & & & & & & \\
\hline & & RR190.70F & ATGGCGAATATTTCTCCAAAAA & \multirow[t]{2}{*}{535} & $94 / 30$ & $50 / 30$ & $72 / 30$ & 5 & \multirow[t]{2}{*}{ (3) } \\
\hline & & RR190.602R & AGTGCAGCATTCGCTCCССCT & & $94 / 30$ & $54 / 30$ & $72 / 30$ & 30 & \\
\hline & \multirow[t]{4}{*}{ gltA } & GLTA1F & GACGGTGATAAAGGAATCTTG & \multirow[t]{2}{*}{1022} & \multirow[t]{2}{*}{$95 / 20$} & \multirow[t]{2}{*}{$47 / 30$} & \multirow[t]{2}{*}{$72 / 60$} & \multirow[t]{2}{*}{40} & \multirow[t]{4}{*}{$(5)$} \\
\hline & & GLTA1R & САTTTCTTTCCATTGTGCCATC & & & & & & \\
\hline & & GLTA2F & CTACGAACTTACCGCTATTAG & 446 & $95 / 20$ & $43 / 30$ & $72 / 30$ & 5 & \\
\hline & & GLTA2R & GACCAAAACCCATTAACCTAAAC & & $95 / 20$ & $48 / 30$ & $72 / 30$ & 30 & \\
\hline & $17 \mathrm{kDa}$ & Rr17k.1p & TTTACAAAATTCTAAAAACCAT & 539 & $95 / 30$ & $57 / 60$ & $72 / 120$ & 35 & $(6)$ \\
\hline & & Rr17k.539n & TCAATTCACAACTTGCCATT & & & & & & \\
\hline & & Rr17k.90p & GCTCTTGCAACTTCTATGTT & 450 & $95 / 30$ & $57 / 60$ & $72 / 120$ & 35 & \\
\hline & & Rr17k.539n & TCAATTCACAACTTGCCATT & & & & & & \\
\hline Anaplasma & groEL & GR0607F & GAAGATGCWGTWGGWTGTACKGC & 688 & $95 / 30$ & $54 / 30$ & $72 / 60$ & 30 & (7) \\
\hline זा & & GR01294R & AGMGCTTCWCCTTCWACRTCYTC & & & & & & \\
\hline & & GR0677F & ATTACTCAGAGTGCTTCTCARTG & 445 & $95 / 30$ & $57 / 30$ & $72 / 60$ & 30 & \\
\hline & & GR01121R & TGCATACCRTCAGTYTTTTCAAC & & & & & & \\
\hline & ankA & ANK-F1 & GAAGAAATTACAACTCCTGAAG & 705 & $95 / 30$ & $53 / 30$ & $72 / 60$ & 35 & $(8)$ \\
\hline & & ANK-R1 & CAGCCAGATGCAGTAACGTG & & & & & & \\
\hline & & ANK-F2 & TTGACCGCTGAAGCACTAAC & 664 & $95 / 30$ & $52 / 30$ & $72 / 60$ & 5 & \\
\hline & & ANK-R2 & ACCATTTGCTTCTTGAGGAG & & $95 / 30$ & $54 / 30$ & $72 / 60$ & 25 & \\
\hline Borrelia species & pyrG & pyrG-1F & ATTGCAAGTTCTGAGAATA & 801 & $94 / 20$ & $45 / 30$ & $72 / 30$ & 30 & $(9)$ \\
\hline & & pyrG-1R & CAAACATTACGAGCAAATTC & & & & & & \\
\hline & & pyrG-2F & GATATGGAAAATATTTTATTTATTG & 707 & $95 / 30$ & $45 / 30$ & $72 / 30$ & 5 & \\
\hline & & & & & $95 / 30$ & $47 / 30$ & $72 / 30$ & 5 & \\
\hline & & pyrG-2R & AAACCAAGACAAATTCCAAG & & $95 / 30$ & $49 / 30$ & $72 / 30$ & 25 & \\
\hline $\begin{array}{l}\text { Bartonella } \\
\text { species }\end{array}$ & ITS & ITS_OF & TTCAGATGATGATCCCAAGC & 639 & $95 / 30$ & $48 / 30$ & $72 / 60$ & 5 & $(10)$ \\
\hline & & ITS_OR & AACATGTCTGAATATATCTTC & & $95 / 30$ & $50 / 30$ & $72 / 60$ & 30 & \\
\hline & & ITS_IF & CCGGAGGGCTTGTAGCTCAG & 499 & $95 / 30$ & $41 / 30$ & $72 / 60$ & 30 & \\
\hline & & ITS_IR & CACAATTTCAATAGAAC & & & & & & \\
\hline Coxiella burnetii & IS1111 & IS111F1 & TACTGGGTGTTGATATTGC & 485 & $95 / 15$ & $52 / 5$ & $72 / 30$ & 35 & $(11)$ \\
\hline & & IS111R1 & CCGTTTCATCCGCGGTG & & & & & & \\
\hline & & IS111F2 & GTAAAGTGATCTACACGA & 260 & $95 / 15$ & $56 / 15$ & $72 / 15$ & 30 & \\
\hline & & IS111R2 & TTAACAGCGCTTGAACGT & & & & & & \\
\hline Babesia species & $\begin{array}{l}18 S \\
\text { rDNA }\end{array}$ & Bab5 & AATTACCCAATCCTGACACAGG & 485 & $94 / 60$ & $55 / 60$ & $72 / 120$ & 35 & $(12)$ \\
\hline & & Bab8 & TTTGGCAGTAGTTCGTCTTTAACA & & & & & & \\
\hline & & Bab6 & GACACAGGGGGTAGTGACAAGA & 407 & $94 / 60$ & $55 / 60$ & $72 / 120$ & 30 & \\
\hline & & Bab7 & СССААСТGСТССТАTTAАССАTTAC & & & & & & \\
\hline Ticks & $\begin{array}{l}16 S \\
\text { rDNA }\end{array}$ & $16 S+1-F$ & CTGCTCAATGAATATTTAAATTGC & 450 & $95 / 45$ & $55 / 60$ & $72 / 90$ & 40 & $(13)$ \\
\hline
\end{tabular}

a ompA, outer membrane protein A gene; gltA, citrate synthase gene; $17 \mathrm{kDa}, 17 \mathrm{kDa}$ protein gene; groEL, heat shock protein gene; ankA, ankyrin-related protei gene; pyrG, CTP synthase gene; ITS, 16S-23S internal transcribed spacer region; IS1111, htpAB-associated repetitive element; 18S rDNA, 18S ribosomal RNA gene; $16 \mathrm{~S}$ rDNA, $16 \mathrm{~S}$ ribosomal RNA gene 
a ompA, outer membrane protein A gene; gltA, citrate synthase gene; $17 \mathrm{kDa}, 17 \mathrm{kDa}$ protein gene; groEL, heat shock protein gene; ankA, ankyrin-related protei gene; pyrG, CTP synthase gene; ITS, 16S-23S internal transcribed spacer region; IS1111, htpAB-associated repetitive element; 18S rDNA, 18S ribosomal RNA gene; $16 \mathrm{~S}$ rDNA, $16 \mathrm{~S}$ ribosomal RNA gene

For N-PCR, the reaction mixture was identical to that used in C-PCR, except that the first PCR product was used as template DNA, and the N-PCR primers were included. With each PCR run, a positive and a negative control (molecular grade water) were included.

All amplifications were performed in an AB thermal cycler (Applied Biosystem, Foster City, CA, USA). The amplified products were separated by electrophoresis on a $1.2 \%$ agarose gel, and stained with ethidium bromide for visualization.

\section{Sequencing and phylogenetic analysis}

The amplified PCR products were purified using QIAquick PCR purification kits (QIAGEN, Hilden, Germany) and sequenced with the PCR primers at Solgent Inc. (Daejeon, Korea). The sequences obtained in this study were compared for similarity with the GenBank sequences using BLAST. Gene sequences, excluding the primer regions, were aligned using the multisequence alignment program in Lasergene version 8 (DNASTAR, USA).

Phylogenetic trees were constructed using ClustalW of the MegAlign Program (DNASTAR, USA) based on the alignments of positive gene sequences using the neighbor-joining method. Bootstrap analysis (1,000 replicates) was performed according to the Kimura 2-parameter method. Pairwise alignments were performed with an open-gap penalty of 10 and a gap extension penalty of 0.5 .

\section{Results}

\section{Tick identification}

We obtained 33 ticks from 30 tick-bitten humans. Out of these, 15 ticks (45.5\%) were adults, namely 12 females and 3 males, and 18 ticks (54.5\%) were nymphs. Based on morphological examination using a microscope for tick identification, the ticks were identified as Amblyomma testudinarium (20, $60.6 \% ; 7$ adults and 13 nymphs), Haemaphysalis longicornis (9, 27.3\%; 5 adults and 4 nymphs), and Ixodes nipponensis (4, 12.1\%; 3 adults and 1 nymph), as described in Table 2. Tick identification using 16S rDNA C-PCR and DNA sequencing yielded the same results as the microscopic examination with the exception of four samples without tick DNA (shown in Table 4).

Table 2

Developmental stages and species of ticks removed from tick-bitten humans determined by both morphological identification and 16S rDNA-targeting conventional PCR

\begin{tabular}{|lllll|}
\hline Tick species & & Amblyomma testudinarium & Heamaphysalis longicornis & Ixodes nipponensis \\
\hline \multirow{2}{*}{ Development stage } & Adult female & 4 & 5 & 3 \\
\cline { 2 - 6 } & Adult male & 3 & 0 & 0 \\
\cline { 2 - 5 } & Nymph & 13 & 4 & 1 \\
\hline & Larva & 0 & 0 & 0 \\
\hline & Total No. (\%) & $20(60.6 \%)$ & $9(27.3 \%)$ & $4(12.1 \%)$ \\
\cline { 3 - 5 } & & $33(100 \%)$ & & \\
\cline { 3 - 5 } & & &
\end{tabular}


Characteristics of 33 ticks using the DNA of tick-borne pathogens obtained from 30 tick-bitten humans

\begin{tabular}{|c|c|c|c|c|c|c|c|}
\hline \multirow{2}{*}{$\begin{array}{l}\text { Patient } \\
\text { no. }\end{array}$} & \multirow{2}{*}{$\begin{array}{l}\text { Patient } \\
\text { age/sex }\end{array}$} & \multirow{2}{*}{$\begin{array}{l}\text { Tick species identified by a } \\
\text { microscopy }\end{array}$} & \multirow{2}{*}{$\begin{array}{l}\text { Development } \\
\text { stage (sex) }\end{array}$} & \multirow{2}{*}{$\begin{array}{l}\text { Identification of ticks by } \\
\text { 16S rDNA PCR }\end{array}$} & \multicolumn{3}{|c|}{ Detected tick-borne pathogens in ticks } \\
\hline & & & & & $\begin{array}{l}\text { SFG } \\
\text { Rickettsia }\end{array}$ & $\begin{array}{l}\text { A. } \\
\text { phagocytophilum }\end{array}$ & $\begin{array}{l}\text { Babesia } \\
\text { spp. }\end{array}$ \\
\hline 1 & $83 / F$ & A. testudinarium & Nymph & NA & - & $\begin{array}{l}\text { A. } \\
\text { phagocytophilum }\end{array}$ & - \\
\hline 2 & $46 / \mathrm{M}$ & A. testudinarium & Nymph & NA & R. tamurae & - & - \\
\hline 3 & $4 / \mathrm{M}$ & A. testudinarium & Nymph & A. testudinarium & - & - & - \\
\hline 4 & NA & A. testudinarium & Nymph & A. testudinarium & - & - & - \\
\hline 5 & $65 / M$ & A. testudinarium & Nymph & A. testudinarium & R. tamurae & - & - \\
\hline 6 & $74 / \mathrm{M}$ & A. testudinarium & Nymph & A. testudinarium & R. tamurae & - & - \\
\hline 7 & $58 / F$ & A. testudinarium & Nymph & A. testudinarium & R. tamurae & - & - \\
\hline 8 & $52 / F$ & A. testudinarium & Nymph & A. testudinarium & - & - & - \\
\hline 9 & $62 / F$ & A. testudinarium & Nymph & A. testudinarium & - & - & - \\
\hline 10 & $60 / \mathrm{M}$ & A. testudinarium & Nymph & A. testudinarium & - & - & - \\
\hline 11 & $55 / F$ & A. testudinarium & Nymph & A. testudinarium & - & - & - \\
\hline 12 & $30 / F$ & A. testudinarium & Nymph & A. testudinarium & & - & $\begin{array}{l}\text { B. } \\
\text { microti }\end{array}$ \\
\hline 13 & $71 / \mathrm{M}$ & A. testudinarium & Nymph & A. testudinarium & - & - & - \\
\hline 14 & $64 / M$ & A. testudinarium & Adult (female) & NA & - & - & - \\
\hline 15 & NA & A. testudinarium & Adult (female) & A. testudinarium & $\begin{array}{l}\text { Ca. R. } \\
\text { jingxinensis }\end{array}$ & - & - \\
\hline 16 & $60 / F$ & A. testudinarium & Adult (female) & A. testudinarium & - & - & - \\
\hline \multirow[t]{2}{*}{17} & \multirow[t]{2}{*}{$54 / F$} & A. testudinarium & Adult (female) & A. testudinarium & R. tamurae & - & - \\
\hline & & A. testudinarium & Adult (male) & A. testudinarium & R. tamurae & - & - \\
\hline 18 & $53 / F$ & A. testudinarium & Adult (male) & A. testudinarium & R. tamurae & - & - \\
\hline 19 & $78 / F$ & A. testudinarium & Adult (male) & A. testudinarium & R. tamurae & - & $\begin{array}{l}\text { B. } \\
\text { gibsoni }\end{array}$ \\
\hline \multirow[t]{2}{*}{20} & \multirow[t]{2}{*}{$60 / F$} & H. longicornis & Nymph & H. longicornis & - & - & - \\
\hline & & $\mathrm{H}$. longicornis & Nymph & NA & - & - & - \\
\hline 21 & $83 / F$ & H. longicornis & Nymph & H. longicornis & $\begin{array}{l}\text { Ca. R. } \\
\text { jingxinensis }\end{array}$ & - & - \\
\hline 22 & $72 / F$ & H. longicornis & Nymph & H. longicornis & - & - & - \\
\hline \multirow[t]{2}{*}{23} & \multirow[t]{2}{*}{$76 / F$} & H. longicornis & Adult (female) & H. longicornis & - & - & - \\
\hline & & H. longicornis & Adult (female) & H. longicornis & - & - & - \\
\hline 24 & $77 / F$ & H. longicornis & Adult (female) & H. longicornis & $\begin{array}{l}\text { Ca. R. } \\
\text { jingxinensis }\end{array}$ & - & - \\
\hline 25 & $5 / \mathrm{M}$ & H. longicornis & Adult (female) & H. longicornis & - & - & $\begin{array}{l}\text { B. } \\
\text { microti }\end{array}$ \\
\hline 26 & $54 / F$ & H. longicornis & Adult (female) & H. longicornis & - & - & - \\
\hline 27 & $77 / F$ & I. nipponensis & Nymph & I. nipponensis & - & - & - \\
\hline 28 & $72 / \mathrm{M}$ & I. nipponensis & Adult (female) & I. nipponensis & - & - & - \\
\hline 29 & $53 / F$ & I. nipponensis & Adult (female) & I. nipponensis & - & $\begin{array}{l}\text { A. } \\
\text { phagocytophilum }\end{array}$ & - \\
\hline 30 & $81 / F$ & I. nipponensis & Adult (female) & I. nipponensis & $\begin{array}{l}\mathrm{R} \text {. } \\
\text { monacensis }\end{array}$ & $\begin{array}{l}\text { A. } \\
\text { phagocytophilum }\end{array}$ & - \\
\hline
\end{tabular}


We examined 33 ticks for the detection of tick-borne pathogens using pathogen-specific nested PCR. The presence of tick-borne pathogens was detected in 16 ticks. From the results, 12 ticks (36.4\%) tested positive for spotted fever Rickettsia, namely R. monacensis (1 of 33, 3.0\%), R. tamurae (8 of 33, $24.2 \%)$, and Candidatus Rickettsia jingxinensis (3 of $33,9.1 \%)$. Three ticks (9.1\%) were positive for A. phagocytophilum, while another three ticks ( $9.1 \%$ ) were positive for either B. gibsoni (1 of 33, 3.0\%) or B. microti (2 of 33, 6.0\%) (Table 3). All ticks were negative for Borrelia spp., Bartonella spp., and C. burnetii.

Table 3

Detection of tick-borne pathogens in ticks by pathogen-specific nested PCR

\begin{tabular}{|llll|}
\hline Detected pathogens & Positive tick numbers & /Total numbers & PCR positivity (\%) \\
\hline Spotted fever group Rickettsia species & 12 & $/ 33$ & 36.4 \\
\hline R. monacensis & 1 & $/ 33$ & 3.0 \\
\hline R. tamurae & 8 & $/ 33$ & 24.2 \\
\hline Candidatus Rickettsia jingxinensis & 3 & $/ 33$ & 9.1 \\
\hline Anaplama phagocytophilum & 3 & $/ 33$ & 9.1 \\
\hline Babesia species & 3 & $/ 33$ & 9.1 \\
\hline B. gibsoni & 1 & $/ 33$ & 3.0 \\
\hline B. microti & 2 & $/ 33$ & 6.0 \\
\hline Borrelia species & 0 & $/ 33$ & 0 \\
\hline Bartonella species & 0 & $/ 33$ & 0 \\
\hline Coxiella burnetii & 0 & $/ 33$ & 0 \\
\hline
\end{tabular}

Of the three A. phagocytophilum-positive ticks, one tick was identified as A. testudinarium, and two ticks were identified as I. nipponensis. Of the 12 SFG Rickettsia-positive ticks, nine ticks were identified as A. testudinarium, two ticks were identified as H. longicornis, and one tick was identified as I. nipponensis. The presence of R. tamurae was identified only in A. testudinarium tick. Of the three ticks detected with Babesia spp., two ticks were A. testudinarium and one tick was $\mathrm{H}$. longicornis. Among the 33 ticks, one I. nipponensis (adult female) was co-infected with A. phagocytophilum and R. monacensis. In addition, coinfections of R. tamurae and Babesia spp. were identified in A. testudinarium (adult male) that presented in Table 4.

\section{Sequencing and phylogenetic analysis}

The positive PCR products were sequenced and the sequencing results were aligned with the sequences obtained from the GenBank database to identify known sequences with a high degree of similarity using ClustalW. The neighbor-joining tree was constructed using the Kimura 2-parameter model (1,000 bootstrap replicates).

The partial ankA sequences obtained from A. phagocytophilum positive-tick demonstrated $99 \%$ similarity with A. phagocytophilum (accession no. KJ677106 and KT986059, 98\% bootstrap support, Fig. 1A). The partial ankA sequences formed a cluster with the A. phagocytophilum strains isolated from humans in the ROK. The partial groEL sequences obtained from A. phagocytophilum-positive ticks demonstrated $99 \%$ similarity with the A. phagocytophilum strain isolated from humans and dogs in the ROK (accession no. KU519286, 66\% bootstrap support, Fig. 1B).

The partial $17 \mathrm{kDa}$, ompA, and gltA sequences obtained from SFG Rickettsia-positive ticks showed 99-100\% similarity with R. tamurae, R. monacensis, and Ca. R. jingxinensis. A phylogenetic analysis grouped the partial gltA sequences with R. tamurae (accession no. KT753273, 86\% bootstrap support, Fig. 1C), R. monacensis (accession no. NZ LN794217, 92\% bootstrap support, Fig. 1C), and Ca. R. jingxinensis (accession no. KT899089, 76\% bootstrap support, Fig. 1C).

The partial 18S rDNA sequences obtained from two Babesia species-positive ticks (Tick 12 and Tick 25) showed 99\% similarity with a B. microti strain isolated from humans in the USA and a tick in China (accession no. KU204794 and LC314655, 100\% bootstrap support, Fig. 1D). Another partial 18S rDNA sequence obtained from Tick 19 had $99 \%$ similarity with B. gibsoni and 100\% similarity with Babesia spp., which were clustered with a B. gibsoni strain isolated from a boar in China (accession no. JX962780, 100\% bootstrap support, Fig. 1D) and Babesia spp. from a tick in Japan (accession no. LC169083, $96 \%$ bootstrap support, Fig. 1D).

\section{Discussion}

Recently, the risk of tick-borne disease has been associated with exposure to ticks from increasing outdoor activity. This study was performed to detect and identify the tick-borne pathogens in ticks removed from tick-bitten humans. We classified 33 ticks into three species: A. testudinarium (20, $60.6 \%$; 7 adults and 13 nymphs) was the most common followed by H. longicornis (9, 27.3\%; 5 adults and 4 nymphs) and I. nipponensis (4, $12.1 \%$; 3 adults and 1 nymph). According to a tick survey study conducted by the KCDC (Korea Centers for Disease Control and Prevention) from 2013 to 2015 , $\mathrm{H}$. longicornis was the most dominant species (88.9\%), followed by H. flava, I. nipponensis, I. persulcatus, H. japonica, A. testudinarium, and I. granulatus when ticks were collected from the vegetation and forests in the ROK using dry-ice bait traps and a flagging method (14). Interestingly, our results showed that when ticks were collected from tick-bitten humans, A. testudinarium was the most common.

For the molecular detection of tick-borne pathogens, we performed pathogen-specific N-PCR to detect the DNA of the tick-borne pathogens, namely SFG Rickettsia, A. phagocytophilum, Borrelia spp., Bartonella spp., Babesia spp., and C. burnetii. Three tick samples (3 of 33, 9.1\%) were positive for A.

Page 6/10 
phagocytophilum DNA, 12 tick samples (12 of 33, 36.4\%) were positive for R. monacensis, R. tamurae or Ca. R. jingxinensis DNA, and three ticks (3 of 33, 9.1\%) were positive for B. gibsoni or B. microti DNA. Previous studies that investigated the prevalence of tick-borne infectious agents in ticks collected by dragging and flagging grass vegetation in the ROK showed that A. phagocytophilum was detected in $1.9 \%$ of $\mathrm{H}$. longicornis ticks (15) and $0.1 \%$ of I. persulcatus ticks, and Rickettsia spp. were detected in $1.7 \%$ of $\mathrm{H}$. longicornis ticks (16). One study reported that a pool of $\mathrm{H}$. longicornis, $\mathrm{H}$. flava, and I. nipponensis ticks collected by dragging vegetation in the ROK were positive for the Rickettsia spp. $17 \mathrm{kDa}$ antigen (60/311, 19.3\%) and ompA gene (53/311, $17.04 \%$ ) (17). In the present study, the infection prevalence of Rickettsia species (R. monacensis, R. tamurae, and Ca. R. jingxinensis) and A. phagocytophilum in the ticks collected from humans was higher than that of ticks collected from the vegetation. Thus, we suggest that further study is needed to compare the infection prevalence of tick-borne pathogens, including Rickettsia spp., A. phagocytophilum, and Babesia between ticks isolated from humans and ticks collected from grass vegetation.

A. phagocytophilum infection was first reported with serological evidence from humans in 2002, and it is currently the most frequently reported tick-borne bacterial infection in the ROK (18). The detection of Anaplasma spp. in ticks from grazing cattle collected from all ROK provinces has been reported (19). Another study confirmed a human granulocytic anaplasmosis (HGA) with A. phagocytophilum in a patient from the ROK who had a history of tick bites, clinical symptoms, and positive laboratory findings (20). The present results showed that A. phagocytophilum was detected in A. testudinarium and I. nipponensis ticks. The amplicon sequences of the partial ankA gene in A. testudinarium (Tick 1) and I. nipponensis (Tick 29 and Tick 30) demonstrated more than $99 \%$ similarity. In the phylogenetic analysis, the sequences of the ankA gene from different types of ticks clustered together, showed $>99 \%$ similarity with A. phagocytophilum strains isolated from humans in the ROK (Fig. 1A).

The first isolation of R. monacensis from ticks in the ROK was reported in 2013 (21). A previous study from the ROK reported that I. nipponensis was infected with the human pathogen R. monacensis and that $\mathrm{H}$. longicornis and $\mathrm{H}$. flava were infected with unknown SFG Rickettsia pathogens (17). Our results confirmed the presence of R. monacensis in I. nipponensis ticks removed from humans. In addition, our results indicated that I. nipponensis ticks are most likely the vectors responsible for transmitting R. monacensis infections in the ROK. Therefore, further studies are needed to determine the role of I. nipponensis in the transmission of the R. monacensis pathogen to humans; the blood of patients bitten by I. nipponensis ticks and the ticks themselves should be investigated for the presence of R. monacensis.

R. tamurae was first isolated from A. testudinarium ticks collected in Japan in 1993. R. tamurae was formally identified as a novel species by genetic and phylogenetic analyses in 2006 (22). In 2011, the first case of human infection was confirmed using molecular and serological analyses in Japan (23). The presence of SFG Rickettsia including R. tamurae was found in Amblyomma and Dermacentor ticks in Thailand (24) and in Haemaphysalis ticks in Peninsular Malaysia (25). In addition, R. tamurae was found in Amblyomma ticks from an area endemic for Brazilian spotted fever in Brazil (26). Supporting these previous studies, our results showed the presence of R. tamurae in A. testudinarium ticks.

The presence of a potentially novel species of Ca. R. jingxinensis was proposed in H. longicornis nymphs from Jingxin in Northeastern China in 2016 (27) and was detected in H. longicornis ticks in Xi'an, China in 2017 (28). In the ROK, the pathogenicity of Ca. R. jingxinensis is not clear. Therefore, a further assessment of the potential pathogenicity in humans and animals is needed.

There have been no previous reports of R. tamurae or Ca. R. jingxinensis from ticks in the ROK; here, we report the first identification of R. tamurae and Ca. R. jingxinensis in ticks obtained from tick-bitten humans.

Babesia was first discovered in animals by Babes in 1988, and more than 100 species have been identified. In the ROK, Babesia spp. have been isolated from cattle and other mammals (raccoon, deer, and badger) since the 2000s (29-31). Babesia spp. are mainly carried by Ixodes ticks. Previous studies using ticks collected from grass and vegetation in the ROK reported that $\mathrm{H}$. longicornis was the most common tick species infected with Babesia (16, 19). Our results showed that B. microti was found in both $\mathrm{H}$. longicornis and A. testudinarium. In the USA, the primary vector for the transmission of B. microti to humans is the tick Ixodes scapularis in the nymphal stage (32). The present results suggest that further study is needed to determine the type of ticks that are the vectors for the transmission of B. microti to humans in the ROK.

B. gibsoni was first identified in nymphs of Rhipicephalus sanguineus ticks from infected dogs in Asia (33). B. gibsoni was detected in A. testudinarium ticks in this study. The first case of human babesiosis (KO1) was reported in 2007 in the ROK, and it was highly related to Chinese ovine Babesia spp. (12). Based on the phylogenetic analysis of the $18 \mathrm{~S}$ rDNA gene in our study, the pathogen clustered with a group of Babesia spp., isolated from a tick in Japan, which was diverged from the K01 strain (Fig. 1D). The present results indicate that Babesia spp. may vary based on their geographical distributions.

Further investigation is needed to determine the difference between pathogens found in ticks isolated from humans and ticks collected from grass vegetation. In addition, transmission studies should be conducted to determine whether the pathogens found in ticks are the same as those found in humans bitten by those ticks. To confirm the transmission of pathogens from ticks to humans, serological testing on the blood of tick-bitten patients and their ticks will be necessary. Further experiments and correlation analysis using the blood samples of tick-bitten humans and ticks isolated from them may help predict the transmission of tick-borne diseases.

\section{Conclusions}

In conclusion, we confirmed three tick species carrying tick-borne pathogens; the most common species was A. testudinarium followed by H. longicornis and I. nipponensis. These ticks were positive for SFG Rickettsia, A. phagocytophilum, and Babesia. This was the first report of the presence of R. tamurae and Ca. R. jingxinensis in ticks removed from tick-bitten humans in the ROK.

\section{Abbreviations}


ROK

Republic of Korea

PCR

polymerase chain reaction

SFG

spotted fever group

IRB

institutional review board

PBS

phosphate-buffered saline

$\mathrm{PC} / \mathrm{SM}$

penicillin and streptomycin

ompA

outer membrane protein A gene

gltA

citrate synthase gene

$17 \mathrm{kDa}$

$17 \mathrm{kDa}$ protein gene

groEL

heat shock protein gene

ankA

ankyrin-related protein gene

pyrG

CTP synthase gene

ITS

16S-23S internal transcribed spacer region

IS1111

htpAB-associated repetitive element

C-PCR

conventional PCR

$\mathrm{N}-\mathrm{PCR}$

nested PCR

\section{Declarations}

\section{Ethics approval and consent to participate}

This study was approved by the Ethics in Human Research Committee of Chosun University Hospital under an institutional review board (IRB), which approved all the experiments that used ticks removed from tick-bitten humans (approval no. CHOSUN NON2019-001). The IRB has been approved without written consent for the use of ticks and not human subject.

\section{Consent for publication}

Not applicable

\section{Availability of data and materials}

The data supporting the conclusions of this article are included within the article.

\section{Competing interests}

The authors declare that they have no competing interests.

\section{Funding}

This study was supported by research fund from Chosun University, 2019. The funders had no role in study design, data collection and analysis, decision to publish, or preparation of the manuscript.

\section{Authors information}

\section{Affiliations}

${ }^{1}$ Departments of Internal Medicine, College of Medicine, Chosun University, Gwangju, Republic of Korea

${ }^{2}$ Premedical Science, College of Medicine, Chosun University, Gwangju, Republic of Korea 
${ }^{3}$ Departments of Biomedical Sciences, Graduate School of Chosun University, Gwangju, Republic of Korea

\section{Contributions}

MS Bang performed the investigation and drafted the manuscript. CM Kim contributed the methodology and revised the manuscript. SH Pyun contributed the investigation. DM Kim contributed the conceptualization, supervision and revised the manuscript. NR Yun supervised. All authors read and approved the final manuscript.

\section{Corresponding author}

Correspondence to DM Kim

\section{Acknowledgements}

Not applicable

\section{References}

1. de La Fuente J, Antunes S, Bonnet S, Cabezas-Cruz A, Domingos AG, Estrada-Peña A, et al. Tick-pathogen interactions and vector competence: identification of molecular drivers for tick-borne diseases. Frontiers in cellular and infection microbiology. 2017;7:114.

2. Im JH, Baek J, Durey A, Kwon HY, Chung M-H, Lee J-S. Current Status of Tick-Borne Diseases in South Korea. Vector-Borne and Zoonotic Diseases. 2019;19(4):225-33.

3. Regnery RL, Spruill CL, Plikaytis B. Genotypic identification of rickettsiae and estimation of intraspecies sequence divergence for portions of two rickettsial genes. Journal of bacteriology. 1991;173(5):1576-89.

4. Roux V, Fournier P-E, Raoult D. Differentiation of spotted fever group rickettsiae by sequencing and analysis of restriction fragment length polymorphism of PCR-amplified DNA of the gene encoding the protein rOmpA. Journal of clinical microbiology. 1996;34(9):2058-65.

5. Jado I, Oteo JA, Aldámiz M, Gil H, Escudero R, Ibarra V, et al. Rickettsia monacensis and human disease, Spain. Emerging infectious diseases. 2007;13(9):1405.

6. Yamaguti N, Tipton VJ, Keegan HL, Toshioka S. Ticks of Japan, Korea, and the Ryukyu islands. Brigham Young University Science Bulletin, Biological Series. 1971;15(1):1.

7. Pritt BS, Sloan LM, Johnson DKH, Munderloh UG, Paskewitz SM, McElroy KM, et al. Emergence of a new pathogenic Ehrlichia species, Wisconsin and Minnesota, 2009. New England Journal of Medicine. 2011;365(5):422-9.

8. Massung RF, Levin ML, Munderloh UG, Silverman DJ, Lynch MJ, Gaywee JK, et al. Isolation and propagation of the Ap-Variant 1 strain of Anaplasma phagocytophilum in a tick cell line. Journal of clinical microbiology. 2007;45(7):2138-43.

9. Sapi E, Pabbati N, Datar A, Davies EM, Rattelle A, Kuo BA. Improved culture conditions for the growth and detection of Borrelia from human serum. International journal of medical sciences. 2013;10(4):362.

10. Ko S, Kang JG, Kim HC, Klein TA, Choi KS, Song JW, et al. Prevalence, Isolation and Molecular Characterization of B artonella Species in Republic of K orea. Transboundary and emerging diseases. 2016;63(1):56-67.

11. Fenollar F, Fournier P, Raoult D. Molecular detection of Coxiella burnetii in the sera of patients with Q fever endocarditis or vascular infection. Journal of clinical microbiology. 2004;42(11):4919-24.

12. Kim J-Y, Cho S-H, Joo H-N, Tsuji M, Cho S-R, Park I-J, et al. First case of human babesiosis in Korea: detection and characterization of a novel type of Babesia sp.(KO1) similar to ovine babesia. Journal of clinical microbiology. 2007;45(6):2084-7.

13. Tian Z, Liu G, Xie J, Yin H, Luo J, Zhang L, et al. Discrimination between Haemaphysalis longicornis and $\mathrm{H}$. qinghaiensis based on the partial $16 \mathrm{~S}$ rDNA and the second internal transcribed spacer (ITS-2). Experimental and applied acarology. 2011;54(2):165-72.

14. Song B, Lee W, Ju Y. Geographical distribution of Ixodid ticks in the Republic of Korea, 2015. Public Health Wkly Rep. 2017;10(10):239-45.

15. Oh JY, Moon B-C, Bae BK, Shin E, Ko YH, Kim Y-J, et al. Genetic identification and phylogenetic analysis of Anaplasma and Ehrlichia species in Haemaphysalis longicornis collected from Jeju Island, Korea. Journal of Bacteriology and Virology. 2009;39(4):257-67.

16. Kim C-M, Yi Y-H, Yu D-H, Lee M-J, Cho M-R, Desai AR, et al. Tick-borne rickettsial pathogens in ticks and small mammals in Korea. Appl Environ Microbiol. 2006;72(9):5766-76.

17. Noh Y, Lee YS, Kim H-C, Chong S-T, Klein TA, Jiang J, et al. Molecular detection of Rickettsia species in ticks collected from the southwestern provinces of the Republic of Korea. Parasites \& vectors. 2017;10(1):20.

18. Heo E-j, Park J-h, Koo J-r, Park M-s, Park M-y, Dumler JS, et al. Serologic and molecular detection of Ehrlichia chaffeensis and Anaplasma phagocytophila (human granulocytic ehrlichiosis agent) in Korean patients. Journal of Clinical Microbiology. 2002;40(8):3082-5.

19. Kang SW, Doan HTT, Choe SE, Noh JH, Yoo MS, Reddy KE, et al. Molecular investigation of tick-borne pathogens in ticks from grazing cattle in Korea. Parasitology international. 2013;62(3):276-82.

20. Kim K-H, Yi J, Oh WS, Kim N-H, Choi SJ, Choe PG, et al. Human granulocytic anaplasmosis, South Korea, 2013. Emerging infectious diseases. 2014;20(10):1708.

21. Lee KM, Choi YJ, Shin SH, Choi MK, Song HJ, Kim HC, et al. Spotted fever group rickettsia closely related to Rickettsia monacensis isolated from ticks in South Jeolla province, Korea. Microbiology and immunology. 2013;57(7):487-95.

Page $9 / 10$ 
22. Fournier P-E, Takada N, Fujita H, Raoult D. Rickettsia tamurae sp. nov., isolated from Amblyomma testudinarium ticks. International journal of systematic and evolutionary microbiology. 2006;56(7):1673-5.

23. Imaoka K, Kaneko S, Tabara K, Kusatake K, Morita E. The first human case of Rickettsia tamurae infection in Japan. Case reports in dermatology. 2011;3(1):68-73.

24. Nooroong P, Trinachartvanit W, Baimai V, Ahantarig A. Phylogenetic studies of bacteria (Rickettsia, Coxiella, and Anaplasma) in Amblyomma and Dermacentor ticks in Thailand and their co-infection. Ticks and tick-borne diseases. 2018;9(4):963-71.

25. Kho KL, Koh FX, Hasan LIM, Wong LP, Kisomi MG, Bulgiba A, et al. Rickettsial seropositivity in the indigenous community and animal farm workers, and vector surveillance in Peninsular Malaysia. Emerging microbes \& infections. 2017;6(1):1-9.

26. Guedes E, Leite RC, Pacheco RC, Silveira I, Labruna MB. Rickettsia species infecting Amblyomma ticks from an area endemic for Brazilian spotted fever in Brazil. Revista Brasileira de Parasitologia Veterinária. 2011;20(4):308-11.

27. Liu H, Li Q, Zhang X, Li Z, Wang Z, Song M, et al. Characterization of rickettsiae in ticks in northeastern China. Parasites \& vectors. 2016;9(1):498.

28. Guo W-P, Huang B, Zhao Q, Xu G, Liu B, Wang Y-H, et al. Human-pathogenic Anaplasma spp., and Rickettsia spp. in animals in Xi'an, China. PLoS neglected tropical diseases. 2018;12(11):e0006916.

29. Cho S-H, Kim T-S, Lee H-W, Tsuji M, Ishihara C, Kim J-T, et al. Identification of newly isolated Babesia parasites from cattle in Korea by using the Bo-RBCSCID mice. The Korean journal of parasitology. 2002;40(1):33.

30. Han J-I, Lee S-J, Jang H-J, Na K-J. Asymptomatic Babesia microti-like parasite infection in wild raccoon dogs (Nyctereutes procyonoides) in South Korea. Journal of wildlife diseases. 2010;46(2):632-5.

31. Hong S-H, Kim H-J, Jeong Y-I, Cho S-H, Lee W-J, Kim J-T, et al. Serological and molecular detection of Toxoplasma gondii and Babesia microti in the blood of rescued wild animals in Gangwon-do (Province), Korea. The Korean journal of parasitology. 2017;55(2):207.

32. Vannier E, Krause PJ. Human babesiosis. New England Journal of Medicine. 2012;366(25):2397-407.

33. Chao L-L, Liao H-T, Ho T-Y, Shih C-M. First detection and molecular identification of Babesia gibsoni from Rhipicephalus sanguineus ticks. Acta tropica. 2017; 166:356-62.

\section{Figures}

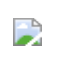

\section{Figure 1}

Phylogenetic trees based on partial nucleotide sequences obtained from A. phagocytophilum-, spotted fever group Rickettsia-, and Babesia-positive ticks in this study and from GenBank. (A) 560 bp of the ankA gene (B) 330 bp of the groEL gene sequences for A. phagocytophilum (C) 420 bp of the gltA gene sequences for SFG Rickettsia (D) 370 bp of the 18S rRNA gene sequences for Babesia species

\section{Supplementary Files}

This is a list of supplementary files associated with this preprint. Click to download.

- Graphicalabstract.tif

- Graphicalabstract.tif 